\title{
Perbanyakan Tanaman Jeruk Siam (Citrus nobilis L.) dengan Teknik Kultur in vitro Menggunakan Biji Tanaman Terinfeksi Penyakit Citrus Vein Phloem Degeneration (CVPD)
}

\section{BAYU ARYA BAGASKARA*), I GEDE PUTU WIRAWAN, MADE SRITAMIN, DAN I GUSTI AYU DIAH YUNITI}

\author{
Program Studi Agroekoteknologi, Fakultas Pertanian, Universitas Udayana \\ J1. P.B. Sudirman Denpasar Bali 80232 \\ ${ }^{*}$ E-mail: bbagaskara57@gmail.com
}

\begin{abstract}
Citrus (Citrus nobilis L.) Propagation Through Culture In Vitro Using Seed From Infected Plants Of Citrus Vein Phloem Degeneration (CVPD) Disease. The sample was taken in Belancan Village, Kintamani District, Bangli Regency, and invitro culture was conducted in UPT. Genetics Resource and Molecular Biology Laboratory in February to June 2018. This research purposes were to get the new citrus plant from citrus seed infected of CVPD disease explants with culture in vitro and found the presence of the bacterium Liberobacter asiaticus in results of citrus plants culture in vitro. The sampling method is using plants appearance. Obtained sample 1 is a plant that shows severe symptoms of CVPD disease and sample 2 plants that show no symptoms of CVPD disease. Seed Sample is cultured with MS0 medium for 8 WAP then proceed to acclimatization. The results of this research showed that the seed explants from both samples were able to grow well and did not have the characteristic of CVPD disease, but explant seed sample 2 in vitro culture result showed that the bacterial DNA bacterium Liberobacter asiaticus pathogen CVPD disease does exist in length 1160bp, so it cannot be expected to produce CVPD-free crops.
\end{abstract}

Keywords: Seed, CVPD Disease, Bacterium Liberobacter asiaticus, DNA, Citrus

\section{PENDAHULUAN}

Jeruk merupakan komuditas hortikultura yang banyak dikonsumsi oleh masyarakat pada umumnya, karena memiliki harga yang terjangkau oleh masyarakat luas dan banyak mengandung vitamin $\mathrm{C}$ yang baik untuk kesehatan. Jenis tanaman jeruk yang paling banyak dibudidayakan dan dikembangkan di Indonesia adalah jeruk siam yang memiliki nama latin Citrus nobilis (Suamba $d k k ., 2014$ ), dengan populasi sekitar
70 sampai 80\% (Suyamto dkk., 2005). Populasi tanaman jeruk di lapangan mengalami peningkatan dari tahun ke tahun, namun sampai saat ini produk buah jeruk siam belum memenuhi harapan karena masalah produktivitas. Penyakit CVPD merupakan salah satu penyebab menurunya masalah produktivitas tanaman jeruk di bali (Wirawan, 2000).

Citrus Vein Phloem Degeneration (CVPD) sering disebut juga "citrus greening" 


\section{BAYU ARYA BAGASKARA. et al. Perbanyakan Tanaman Jeruk Siam (Citrus nobilis L.)...}

atau "Huanglongbin" (Wirawan, 2000). Penyakit CVPD menyerang hampir semua kultivar jeruk yang menyebabkan produksi berkurang, mengalami gagal panen, dan memperpendek masa hidup tanaman (Hung et al., 2000). Bakteri penyebab penyakit CVPD di Indonesia adalah Liberobacter asiaticus yang ditularkan oleh serangga vektor Diaphorinacitri. Wirawan (2000), melaporkan bahwa $83 \%$ serangan penyakit CVPD di Bali disebabkan oleh penyebaran bibit yang telah terinfeksi penyakit CVPD yang dihasilkan melalui teknik penempelan mata tunas. Cara mengetahui secara pasti tanaman yang terserang penyakit CVPD adalah dengan menggunakan teknik Polymerase Chain Reaction (PCR), yang menggunakan primer 16s rDNA spesifik bagi bakteri (Sandrine et al., 1996). Salah satu perbanyakan tanaman jeruk siam adalah dengan teknik in vitro melalui biji. Biji yang berasal dari tanaman jeruk siam terinfeksi penyakit CVPD diduga mengandung bakteri Liberobacter asiaticus yang hanya terdapat pada floem tanaman terinfeksi, karena pengangkutan makanan melalui jaringan floem tempat hidupnya bakteri Liberobacter asiaticus sehingga akan terdapat diseluruh bagian tanaman hingga dipangkal buah bahkan sampai di biji.

Penelitian ini bertujuan untuk Untuk mendapatkan tanaman baru yang berasal dari eksplan biji tanaman jeruk siam bergejala berat penyakit CVPD dengan teknik kultur in vitro, dan untuk menemukan keberadaan bakteri Liberobacter asiaticuspada tanaman jeruk siam hasil kultur in vitro.

\section{METODE PENELITIAN}

Penelitian ini dimulai dari bulan Februari sampai dengan Juni 2018 di Desa Belancan Kecamatan Kintamani Kabupaten Bangli Provinsi Bali dilanjutkan dengan penanaman kultur in vitro dan identifikasi penyakit CVPD secara molekuler di UPT. Laboratorium Sumberdaya Genetika dan Molekuler Universitas Udayana.

Alat yang digunakan adalah timbangan digital, magnetic stirrer, autoclave, microwave/oven, laminair air flow cabinet, inkubator, mesin vortex, water bath, pestle, PCR tube, UV transilluminator, mesin elektroforesis, mesin PCR, kertas parafilm, spatula, kertas label, kamera digital, gelas ukur, backer glas, gelas labu erlenmayer, botol kultur/selai, pinset, pisau, gunting, mortar, mikropipet, dan Eppendort (tabung mikro). Bahan eksplan yang digunakan dalam penelitian ini adalah biji dan daun jeruk siam, aquades, Media MS (Murashige and Skoog), Gellan Gum, Sucrose, B5 Vitamin Stock (Myo-Inositol, ThiamineHCL, Nicotinic Acid, Pyridoxine-HCL), diterjen, benlite, Alcohol 70\%, Natrium Hipoklorit, Tween, Agarose, TAE, DNA genome mini kit plant, PCR Master Mix Solution, Marker DNA 100bp Ladder, Loading Dye, Etidium Bromida, Nitrogen cair, dan sepasang Primer 16s rDNA spesifik CVPD yaitu Forward Primer OI1 dan Reverse Primer OI2c.

\section{Pengambilan sampel jeruk siam}

Penentuan sampel yang akan digunakan pada penelitian ini dilihat dari visual yang ditunjukkan oleh tanaman yang disesuaikan dengan hasil penelitian Melani (2018) yaitu, bergejala berat penyakit CVPD 
dan yang tidak bergejala penyakit CVPD. Tulang daun digunakan pada tahap isolasi DNA dan deteksi PCR yang pertama untuk menentukan secara pasti tanaman yang diambil terinfeksi bakteri Liberobacter asiaticus atau tidak, dan biji tanaman jeruk siam digunakan pada tahap kultur in vitro.

\section{Deteksi penyakit CVPD pada daun jeruk dengan teknik PCR}

Deteksi penyakit CVPD dilakukan dua kali. Pertama saat pengambilan eksplan kultur, dan yang kedua adalah hasil dari kultur in vitro biji jeruk siam. Bagian tanaman yang di ambil adalah tulang daun dan biji. Kemudian dilakukan isolasi DNA dan deteksi dengan teknik PCR

Isolasi DNA dilakukan dengan Genomic DNA Mini Kit Plant. Sample tulang daun dan biji jeruk kemudian digerus sampai halus dengan mortar sambil ditambah nitrogen cair dan ditaruh dalam ependorf. Disuspensi dalam lysis buffer 400ul GPL dan ditambahkan 5ul RNase A dan divortex agar bahannya homogen. Hasil dari suspensi tadi ditaruh dalam tabung mikro $1,5 \mathrm{ml}$ dan diinkubasi pada suhu $60^{\circ} \mathrm{c}$ selama 10 menit dengan membolak balikan ependorf selama 5 menit sekali, setelah selesai ditambahkan 100ul GP2 Buffer dan vortex kemudian diinkubasi pada es selama 3 menit (pada saat itu juga elution buffer diinkubasi pada suhu $60^{\circ} \mathrm{c}$ dan selanjutnya akan digunakan pada tahap akhir isolasi DNA) tempatkan filter column pada collection tube kemudian pindahkan suspensi ekstrak tanaman pada filter column dan sentrifuse selama 1 menit pada 1.000xg. Supernatant yang dihasilkan dipindahkan pada collection tube yang baru dan ditambahkan 750ul GP3 buffer kemudian ditempatkan pada GD column selanjutnya disentrifuse pada $14.000-16.000 x g$ selama 2 menit, kemudian ditambahkan 400ul W1 dan disentrifuse pada $14.000-16.000 x g$ selama 30 detik. Cairannya dibuang dan ditaruh pada GD colum pada b2 ml collection tube, tambahkan 600ul wash buffer pada GD colum kemudian disentrifuse 14.000$16.000 x$ g selama 30 detik dibuang cairannya dan GD colum ditempatkan $2 \mathrm{ml}$ collection tube kemudian sentrifuse lagi untuk mengeringkan GD colum. Pindahkan GD colum yang sudah kering ke mikrosentrifus tube lalu tambahkan 100 ul preheated TE buffer atau elution buffer ditengah-tengah GD colum lalu di diemkan 3-5 menit lalu sentrifuse 14.000-16.000xg selama 30 detik. Pellet yang tersisa pada ependof tube merupakan DNA tanaman yang akan digunakan untuk mengetahui hasil isolasi DNA.

Analisis teknik PCR untuk mendeteksi keberadaan bakteri Liberobacter asiaticuspada tanaman yang gejala berat penyakit CVPD dan yang tidak gejala serangan penyakit CVPD, dilakukan dengan menggunakan primer spesifik dari 16s rDNA forward primer OI1 (5' GCG CGT ATG CAA TAC GAG CGG C 3') dan Reverse Primer OI2c (5' GCC TCG CGA CTT CGC AAC CCA T 3'). DNA hasil isolasi diamplifikasi sebanyak 20 ul dengan teknik PCR. Amplifikasi DNA dilakukan sebagai berikut: (1) Perlakuan awal pada suhu $92^{\circ} \mathrm{c}$ selama 30 detik dengan satu siklus ulangan. (2) Empat puluh siklus yang terdiri atas Denaturasi pada suhu $92^{\circ} \mathrm{c}$ selama 60 detik, Aneling pada suhu $60^{\circ} \mathrm{c}$ selama 30 detik dan Elongation pada suhu $72^{\circ} \mathrm{c}$ selama 90 detik. 


\section{BAYU ARYA BAGASKARA. et al. Perbanyakan Tanaman Jeruk Siam (Citrus nobilis L.)...}

(3) Extension pada suhu $72^{\circ} \mathrm{c}$ selama 90 detik dengan siklus ulangan.

\section{Elekroforesis dan visualisasi hasil PCR}

Fragmen DNA hasil amplifikasi PCR di ektroforesis pada gel Agarose 1\%, penyangga untuk elektroforesis digunakan TAE $1 \%$ yang mengandung $40 \mathrm{mM}$ sodium EDTA. Elektroforesis dilakukan pada 100 volt selama satu jam. Selanjutnya DNA hasil elektroforesis dilihat dengan Transiluminator UV.

\section{Persiapan media dan alat kultur in vitro}

Media kultur in vitro yang digunakan adalah Media MSO (Media MS tanpa hormone) medium dengan komposisi: 4,3 g/l MS (murashige and skoog) dipanaskan pada oven dahulu dengan suhu $100^{\circ} \mathrm{c}$ selama 5 menit, ditambah $1 \mathrm{ml} \mathrm{B5}$ vitamin stock (100 $\mathrm{mg} / \mathrm{ml}$ myo-inositol, $10 \mathrm{mg} / \mathrm{ml}$ thiamine$\mathrm{HCL}, 1 \mathrm{mg} / \mathrm{ml}$ nicotinic acid, $1 \mathrm{mg} / \mathrm{ml}$ pyridoxine-HCL), $30 \mathrm{~g} / \mathrm{l}$ sucrose, dan $0,4 \%$ Gellum Gum agar. Media dan alat disterilisasi dengan menggunakan autoklaf pada suhu $121^{\circ} \mathrm{c}$, tekanan 15 psi selama 15 menit untuk media dan 30 menit untuk alat.

\section{Kultur in vitro biji jeruk siam dan aklimatisasi}

Biji jeruk siam yang akan ditanam dalam media dikupas dan disterilkan. Sterilisasi eksplan dilakukan dalam lima tahap, yakni: 1) dicuci bersih dengan diterjen dan fungisida banlite $2 \mathrm{~g} / \mathrm{l}$ selama 10 menit;
2) dibilas dengan aquades sebanyak 3 kali; 3 ) disterilkan dengan alkohol $70 \%$ selama 2-3 menit; 4) disterilkan 2 kali dengan $10 \%$ dan $20 \%$ natrium hipoklorit + Tween selama minimal 5 menit; 5) dibilas dengan aquadest steril sebanyak lima kali. Penanaman eksplan dilakukan dalam Laminair Air Flow Cabinet yang sudah disterilkan. Botol yang telah diisi eksplan diletakkan pada inkubator dengan suhu $28^{\circ} \mathrm{c}$ dan lampu fluorescent. Aklimatisasi di lakukan dengan media campuran tanah subur, pasir, dan arang sekam yang memiliki komposisi $(1,1 / 4,1)$.

\section{HASIL DAN PEMBAHASAN}

Hasil pengamatan secara visual pada areal pertanaman jeruk siam di Desa Blancan, Kecamatan Kintamani, Kabupaten Bangli didapatkan dua sample yaitu tanaman jeruk yang menunjukkan gejala berat (Sample 1) dan yang tidak menunjukkan gejala penyakit CVPD secara visual (Sample 2). Pola A gejala klorosis yang berat pada daun tanaman jeruk hasil penelitian Melani (2018) dan buah (Wirawan dkk., 1998) digunakan sebagai acuan pengambilan sample. Gejala yang tampak pada sampel adalah sebagai berikut:

1. Sampel 1 dengan ciri, menunjukkan hampir keseluruhan tanaman tampak klorosis (Gambar 1.A). klorosis lamina daun sangat jelas (Gambar 1.B). Buah kecil, kulit buah keras, dan warna kuning (Gambar 1.C). 


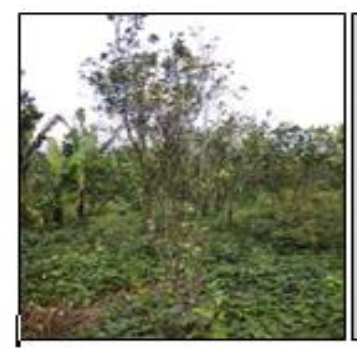

A

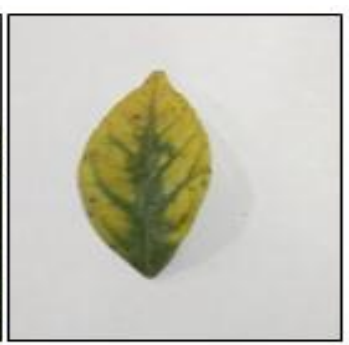

B

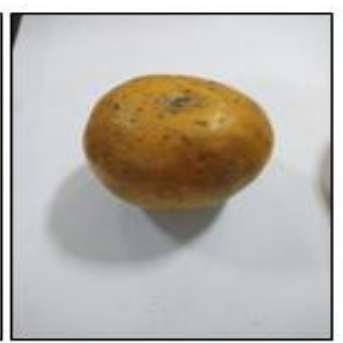

$\mathrm{C}$

Gambar 1. Sample tanaman jeruk siam bergejala penyakit CVPD.

(A) Tanaman Keseluruhan (B) Daun (C) Buah.

2. Sampel 2 dengan ciri, menunjukkan keseluruhan tanaman tidak tampak gejala klorosis (Gambar 2.A). Gejala klorosis juga tidak tampak pada lamina daun (Gambar 2.B), dan buahnya juga tidak menunjukkan pengerasan pada kulit, perubahan warna menjadi kuning, dan ukurannya besar/normal (Gambar 2.C).

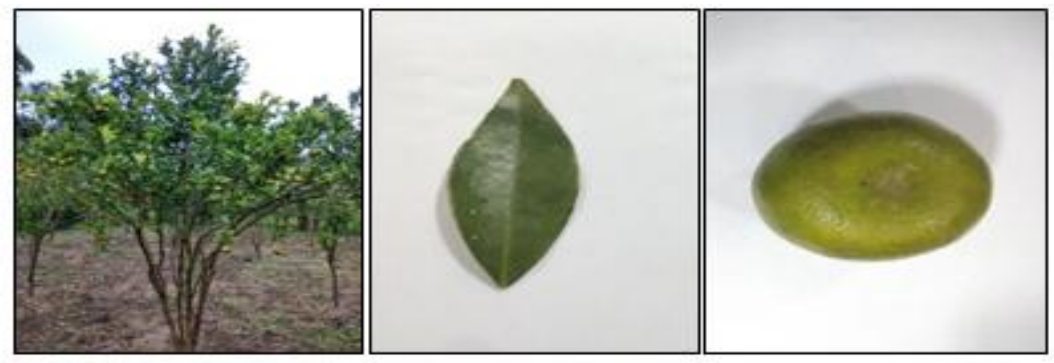

A

B

C

Gambar 2.Sample tanaman jeruk siam yang tidak bergejala penyakit CVPD.

(A) Tanaman Keseluruhan (B) Daun (C) Buah.

Kultur In Vitro Eksplan Biji Tanaman Jeruk Siam

Hasil kultur in vitro dengan eksplan biji tanaman jeruk siam menggunakan media MSO, tidak ditemukan kontaminasi pada keseluruhan sampel 1 dan 2. Kondisi steril merupakan syarat mutlak keberhasilan pelaksanaan kultur in vitro sehingga kondisi ini harus dijaga (Dwiyani, 2015). Hal ini menunjukkan dalam proses sterilisasi dan proses penanaman eksplan yang dilakukan berhasil, sehingga eksplan yang ditanam mampu tumbuh dan membentuk individu baru. 
BAYU ARYA BAGASKARA. et al. Perbanyakan Tanaman Jeruk Siam (Citrus nobilis L.)...

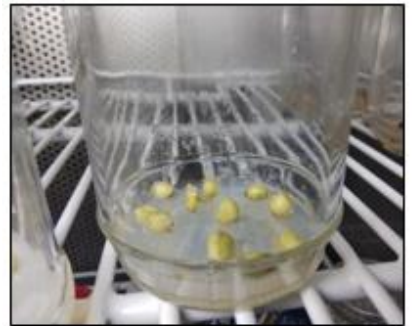

A

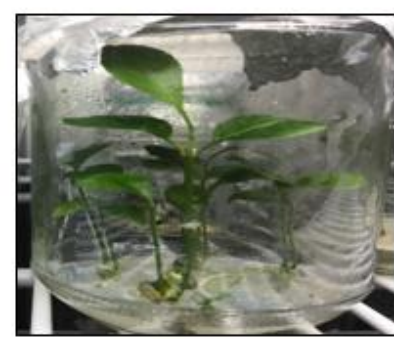

C

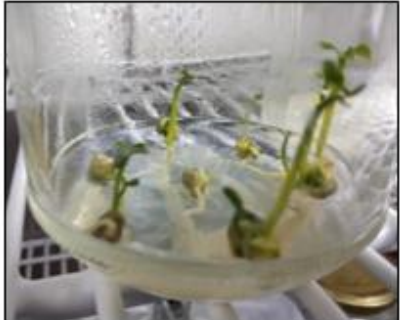

B

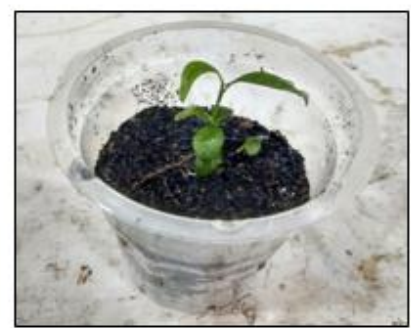

D

Gambar 3. kultur in vitrobiji tanaman jeruk siam sample 1. (A) $1 \mathrm{mst}$ (B) 4 mst (C) 8 mst (D) Aklimatisasi 10 mst.

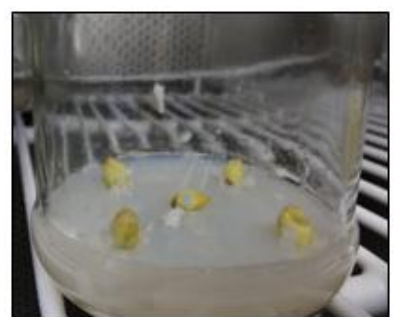

$\mathbf{A}$

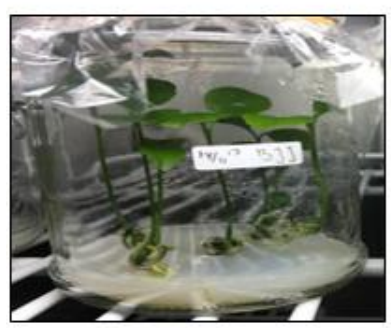

C

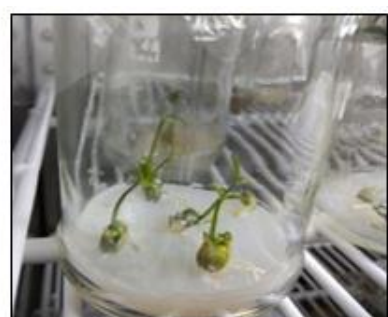

B

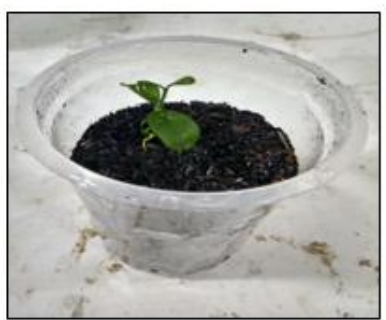

D

Gambar 4. kultur in vitro biji tanaman jeruk siam sample 2 (A) 1 mst (B) 4 mst (C) 8 mst (D) Aklimatisasi $10 \mathrm{mst}$.

Hasil pengamatan didapatkan beberapa perbedaan, terlihat jelas pada 4 mst dan 8MST. Pertumbuhan biji sampel 1 pada 4 mst lebih sedikit dari pada sampel 2 dengan jumlah biji yang terlambat muncul tunas adalah 2 biji. Kotiledon pada 4 mst masih 
terlihat baik sampel 1 maupun 2, sehingga cadangan makanan untuk tanaman masih tersedia. Pada pengamatan 8 mst ditemukan munculnya sifat poliembrioni biji tanaman jeruk siam yang mampu menghasilkan 1 hingga 3 semaian dalam media kultur in vitro.

Aklimatisasi yang dilakukan pada penelitian ini adalah satu tahap yaitu memindahkan eksplan ke media baru dengan campuran tanah subur, pasir, dan arang sekam. Hasil pengamatan aklimatisasi 10 mst didapatkan tanaman sample 1 dan 2 mampu bertahan dan beradaptasi dengan media yang baru, ini dapat dilihat dari munculnya daun ke 3 dan 4 pada tanaman hasil aklimatisasi. Gejala penyakit CVPD pada tanaman hasil aklimatisasi sample 1 dan 2 tidak ditemukan sama sekali.

\section{Deteksi Patogen Penyebab CVPD}

Hasil isolasi DNA total dari tulang daun diperoleh keseluruh DNA total tanaman. Hasil dari DNA total yang telah dielektroforesis dengan gel agarose $1 \%$ dan divisualisasi menggunakan UVtransilluminator menunjukkan bahwa semua sample memiliki DNA (Gambar 5.).Hasil visualisasi total DNA dengan elektroforesis menunjukkan perbedaan antara gambar sample A.1, A.2, B.1 dan B.2. Hasil pada gambar sampel B.2 (Sampel 2 hasil kultur in vitro)terlihat pita DNA yang membentuk garis (pita tunggal) tetapi tidak terlalu tebal sedangkan pada gambar sample A.1 (Sampel 1 dari lapangan), A.2 (Sampel 2 dari lapangan) dan B.2 (Sampel 2 hasil kultur in vitro)terlihat pita DNA yang diperoleh membentuk garis (pita tunggal) tetapi memiliki ekor atau smear.

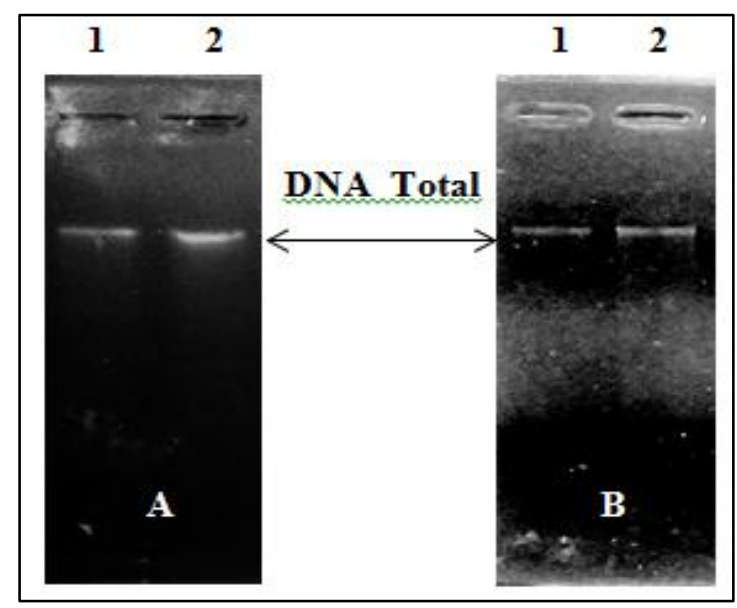

Gambar 5. Hasil elektroforesis dna total dengan gel agarose 1\% (A) Tanaman jeruk siam (B) Tanaman jeruk siam setelah di kultur in vitro (1) Sample 1 (2) Sample 2.

Menurut Irmawati (2003) pita DNA yang tebal dan mengumpul (tidak menyebar) menunjukkan konsentrasi yang tinggi dan
DNA total yang diekstrak dalam kondisi utuh, sedangkan pita DNA yang terlihat smear menunjukkan adanya ikatan antar 
BAYU ARYA BAGASKARA. et al. Perbanyakan Tanaman Jeruk Siam (Citrus nobilis L.)...

molekul DNA yang terputus menjadi bagian yang lebih kecil. Terputusnya ikatan antar molekul tersebut dapat disebabkan oleh adanya gerakan fisik maupun kimiawi yang berlebihan pada saat proses ekstrasi. Hasil DNA total yang didapat kemudian diamplifikasi dengan teknik PCR.
Hasil DNA total diperbanyak pada mesin PCR menggunakan primer spesifik dari 16s rDNA dengan forward primer OI1 dan Reverse Primer OI2c. DNA hasil PCR kemudian dielektroforesis dengan gel agarose $1 \%$ (Gambar 6).

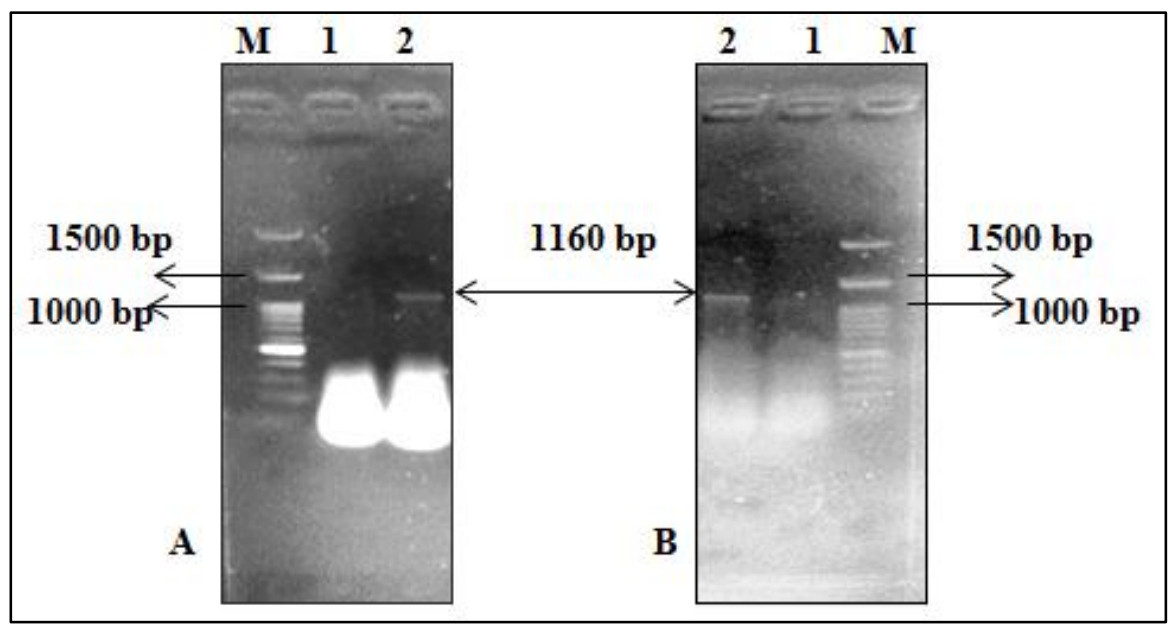

Gambar 6. Elektroforesis hasil PCR dengan gel agarose 1\% (A) Tanaman jeruk siam dari lapangan (B) Tanaman jeruk siam hasil kultur in vitro(M) Marker / penanda (1) Sample 1 (2) Sample 2.

Hasil ini menunjukkan bahwa pada sampel 1 DNA bakteri Liberobacter asiaticus tidak ditemukan, baik pada tanaman yang di lapangan maupun tanaman hasil kultur in vitro, tetapi dilihat secara visual tanaman di lapangan menunjukkan gejala serangan berat penyakit CVPD. Menurut Wirawan dkk. (2003) bahwa tidak semua daun pada ranting tanaman yang sama menunjukkan gejala serangan CVPD positif atau mengandung bakteri Liberobacter asiaticus, dapat terjadi pada daun bagian atas positif mengandung bakteri sedangkan daun bagian bawahnya negatif atau sebaliknya. Pada biji tanaman jeruk siam berpeluang terjadi hal yang sama dengan daun tanaman jeruk siam. Selanjutnya Wirawan dkk. (2003), juga melaporkan bahwa tidak diperlukan adanya patogen pada bagian daun tanaman untuk memunculkan gejala penyakit atau dengan kata lain patogen yang berada pada daun tanaman lain dapat menyebabkan munculnya gejala penyakit CVPD pada daun disebelahnya atau diatas dan dibagian bawahnya. Hasil penelitian Sritamin (2007) menyatakan bahwa hal ini diduga terjadi karena ada interaksi antara dua jenis molekul protein khas pada tanaman yang terserang penyakit CVPD, protein ini diduga merupakan protein virulen atau toksin dari 
bakteri Liberobacter asiaticus dan protein reseptor dari tanaman jeruk. Selanjutnya dikatakan interaksi dari kedua molekul protein ini menyebabkan terhambatnya transport ion ke dalam sel tanaman jeruk dan menyebabkan tanaman kekurangan mineral $\mathrm{Zn}, \quad \mathrm{Mn}, \mathrm{Ca}$, sehingga muncul gejala serangan penyakit CVPD.

Hasil sebaliknya didapatkan pada sampel 2 dari lapangan maupun hasil kultur in vitroditemukan DNA bakteri Liberobacter asiaticus dengan panjang DNA teramplifikasi $1160 \mathrm{bp}$, walaupun secara visual tanaman dilapangan tidak menunjukkan gejala sama sekali tetapi secara molekuler tanaman sampel 2 positif penyakit CVPD. Hasil amplifikasi DNA sampel 2 diatas membuktikan bahwa tanaman yang tidak bergejala klorosis belum tentu terbebas dari bakteri Liberobacter asiaticus, perlu dilakukannya identifikasi secara molekuler dengan teknik PCR. Karena teknik PCR memiliki sifat yang sangat sensitif sehingga hasil yang didapatkan adalah pasti. Hasil dari penelitian ini dapat kita nyatakan bahwa Perbanyakan tanaman jeruk siam dengan menggunakan biji tidak dapat digunakan karena bakteri Liberobacter asiaticus berpeluang terbawa hingga ke biji. Bakteri Liberobacter asiaticus dapat sampai ke biji tanaman jeruk siam karena didalam buah terdapat floem kecil sebagai tempat penyaluran makanan dan tempat tinggal dari bakteri Liberobacter asiaticus.

\section{SIMPULAN}

Kultur in vitro tanaman jeruk siam menggunakan eksplan biji dapat tumbuh dengan baik dan tidak memiliki ciri terserang penyakit CVPD. Tanaman yang dihasilkan melalui kultur in vitro dari eksplan biji yang tidak bergejala penyakit CVPD, ternyata menunjukkan membawa bakteri Liberobacter asiaticus pathogen penyakit CVPD sehingga tidak dapat digunakan untuk menghasilkan tanaman bebas penyakit CVPD.

\section{DAFTAR PUSTAKA}

Dwiyani, R. 2015. Kultur Jaringan Tanaman. Pelawa Sari. Denpasar Barat. 75.

Hung, T.H., Wu, M.L., And Su, H.J. 2000. Detection of fastidious bacteria causing citruss greening disease by nonradioactive DNA probes.

Irmawati. 2003. Perubahan Keragaman Genetika Ikan Kerapu Tikus Generasi Pertama Pada Stok Hatchery. Thesis. Bogor: IPB.

Melani, R. 2018. Deteksi Penyakit Citrus Vein Phloem Degeneration (CVPD) Dengan Teknik Polymerase Chain Reaction(PCR) pada Daun Tanaman Jeruk Yang MemilikiPola Gejala Klorosis Berbeda. E-Jurnal Agroekoteknologi Tropika. 7(2). 164173.

Sandrine, J., J.M. Bove, M. Garnier. 1996. PCR detection of two candidates Liberobacter spesies assosiated with greening disease of citrus. Moleculeran Celluler Probes. 10: 42.

Sritamin, M. 2007. Akumulasi Protein Spesifik $16 \mathrm{kDa}$ (PS16) pada Daun Jeruk Terinfeksi Penyakit Citrus Vein Phloe Degeneration (CVPD). Disertasi (sudah dipublikasi) Universitas Brawijaya Malang.

Suamba, I. W., I. G. P. Wirawan, Dan Wayan Adiartayasa. 2014. Isolasi dan Identifikasi Fungi Mikoriza Arbuskular (Fma)secara Mikroskopis pada Rhizosfer Tanaman Jeruk (Citrus sp.)di Desa Kerta, Kecamatan Payangan, Kabupaten Gianyar. E-Jurnal 
BAYU ARYA BAGASKARA. et al. Perbanyakan Tanaman Jeruk Siam (Citrus nobilis L.)...

Agroekoteknologi Tropika,2(4): 201 208.

Suyamto, Supriyanto A, Agustian A, Triwiratno A, Dan Winarno M. 2005. Prospek dan Arah Pengembangan Agribisnis Jeruk. Badan Penelitian dan Pengembangan Pertanian, Departemen Pertanian, Jakarta.

Wirawan, I.G.P., N. Arya., S. Subandiyah. 1998. Isolasi Loci Resisten Terhadap CVPD dengan Metode Transformasi Menggunakan

Agrobacteriumtumefaciens. Laporan Riset Unggulan Terpadu V. Kantor Menteri Negara Riset Teknologi. Dewan Riset Nasional. Jakarta.

Wirawan, I.G.P. 2000. Isolasi Resisten terhadap CVPD (Citrus Vein Phloem Degeneration) dengan Metode Transformasi Menggunakan Agrobacterium tumefaciens. Laporan Riset Unggulan Terpadu V. Denpasar: Universitas Udayana.

Wirawan, I.G.P., L. Sulistyowati, dan I.N. Wijaya. 2003. Mekanisme Tingkat Molekul Infeksi Penyakit CVPD pada Tanaman Jeruk dan Peran Diaphorinacitri Kuw. sebagai Serangga Vektor. Denpasar. Lemlit. Universitas Udayana. 